\title{
Weep for the Coming of Men: Epidemic and Disease in Anglo-Western Colonial Writing of the South Pacific
}

\author{
Chrystopher J. Spicer
}

https://orcid.org/0000-0003-1369-4497

James Cook University, Australia

\begin{abstract}
During the nineteenth and early twentieth centuries, epidemics ravaged South Pacific islands after contact with Westerners. With no existing immunity to introduced diseases, consequent death tolls on these remote islands were catastrophic. During that period, a succession of significant Anglo-Western writers visited the South Pacific region: Herman Melville, Robert Louis Stevenson, Louis Becke, Jack London, and Fredrick O'Brien. In a remarkable literary conjunction, they each successively visited the Marquesas Islands, which became for them a microcosm of the epidemiological disaster they were witnessing across the Pacific. Instead of the tropical Eden they expected, these writers experienced and wrote about a tainted paradise corrupted and fatally ravaged by contact with Western societies. Even though these writers were looking through the prism of Social Darwinism and extinction discourse, they were all nevertheless appalled at the situation, and their writing is witness to their anguish. Unlike the typical Victorian-era traveller described by Mary Louise Pratt as the "seeing-man", who remained distanced in their writing from the environment around them, this group wrote with the authority of personal felt experience, bearing witness to the horrific impact of Western society on the physical and mental health of Pacific Island populations. The literary voice of this collection of writers continues to be not only a clear and powerful witness of the past, but also a warning to the present about the impact of 'civilisation' on Pacific Island peoples and cultures.
\end{abstract}

Keywords: epidemic disease, South Pacific, Literature, Herman Melville, Robert Louis Stevenson, Louis Becke, Jack London, Fredrick O’Brien

eTropic: electronic journal of studies in the tropics publishes new research from arts, humanities, social sciences and allied fields on the variety and interrelatedness of nature, culture, and society in the tropics. Published by James Cook University, a leading research institution on critical issues facing the world's Tropics. Free open access, Scopus Listed, Scimago Q2. Indexed in: Google Scholar, DOAJ, Crossref, Ulrich's, SHERPA/RoMEO, Pandora. ISSN 1448-2940. Creative Commons CC BY 4.0 free to download, save and reproduce. To cite, include: Author(s), Title, eTropic, volume, issue, year, pages and DOI: http://dx.doi.org/10.25120/etropic.20.1.2021.3783 
eTropic 20.1 (2021) Special Issue: Pandemic, Plague, Pestilence and the Tropics

"Weep, wretched people of Tahiti, weep! But let it be for the coming and not the going of these wicked and ambitious men. One day you will know them better. . . . The day will come when you will be their slaves, as corrupted, as base, as wretched as they themselves"

- Denis Diderot Supplément au Voyage de Bougainville, 1796 (quotation from Judd, 1977, p. 585)

hroughout the island world of the Pacific," observes Robert Louis
Stevenson at the beginning of his novel The Ebb-Tide, "scattered men of
many European races and from almost every grade of society carry activity and disseminate disease" (Stevenson, 1996, p.7). This dissemination made such a rapid, profound, and destructive impact on South Pacific Island societies that the physical symptoms, argues Rod Edmond in Representing the South Pacific, became "a palpable sign of the contaminating power of European civilization." So pervading was the contamination that as the literary trope of the tropical island Paradise developed over time, so too did "a counter-discourse of the diseased Pacific" (1997, p. 194). Alan Moorhead succinctly refers to this contamination as a 'fatal impact', with good reason, because the outcome for Indigenous people was all too frequently death (Campbell, 2011, p. 10). Island populations who had no previous exposure to European viruses were decimated by introduced disease within only a few years, resulting not only in drastic depopulation but also in the consequent loss of orally transmitted cultural histories and practices. As early as 1800 , for example, cholera transmitted by survivors from the wreck of the American schooner Argo killed hundreds of Fijians; this was followed by a ship-borne epidemic of dysentery, and in 1875 a measles epidemic killed an estimated 40,000 people, about one third of the Fijian population (Gravelle, 2012, p. 31, 136). In 1893, a thousand Samoans died during a measles epidemic, while Tahitians were struck down by epidemics of smallpox in 1834, scarlet fever in 1847, and measles in 1854. Measles and whooping cough arrived in Hawai'i on board American ships in 1848 and 1849, killing an estimated 10,000 Islanders. By the end of the nineteenth century, the Indigenous population of Hawai'i had been reduced to 40,000 , the New Zealand Maori population had declined by two-thirds, and by 1926 the population of the Marquesas Islands was reduced to 2,225 from an estimated 50,000. Songs and dances could no longer be performed there, Robert Louis Stevenson remarked, because there was no one alive who remembered the words and movements (Thompson, 2019, p. 23, 153, 154).

During the latter part of the nineteenth century and the early twentieth century, several significant Anglo-Western writers, Herman Melville (1819-1891), Robert Louis 
eTropic 20.1 (2021) Special Issue: Pandemic, Plague, Pestilence and the Tropics

Stevenson (1850-1894), Louis Becke (1855-1913), Jack London (1876-1916), and Frederick O'Brien (1869-1932), experienced and wrote about the impact of Westerners on the Pacific Islands. Remarkably, this collection of writers from widely dispersed geographic locations of America, Scotland, and Australia, ultimately became connected, when, in succession, they visited the same island group - the Marquesas. These writers subsequently produced a body of work that collectively bears witness to the depopulation, loss of custom and language, and physical and moral corruption that was devastating Pacific Island societies. The particular approach in each of their writings distinguishes these writers from the customary European male subject of colonial landscape discourse whom Mary Louise Pratt terms the "seeingman," that is, "he whose imperial eyes passively look out and possess" as the land submissively unfolds before them (1992, p. 7). This 'seeing-man,' she continues, is the protagonist of an "anti-conquest" whereby the passive "landscanning European eye seems powerless to act upon or interact with a landscape that offers itself" (1992, p. 60). Instead, Pratt argues, the writer of sensibility should interact with their environment through language in which the use of ' $l$ ' connects experience to person, giving that interactive written account an authority that "lies in the authenticity of somebody's felt experience" (1992, p. 76). Information has value, she reasons, when it relates to the writer/traveller and their quest (1992, p. 77). Uniquely interrelated by their experiences in the same Pacific Island group, these writers - read together produced a body of work that we can explore in order to perceive their interaction with their environment as, connecting experience to person, they bore authoritative personal witness to the consequences of Islander contact with white outsiders.

Following Herman Melville, each of these writers visited the Marquesas island group because they had read the account of his stay there in his novel Typee (orig. 1846), but their various visits were also part of lengthy periods spent in the South Pacific. They were all, then, more knowledgeable about and experienced with Island peoples and culture than the customary traveller, and so they were less likely to adopt the distanced view of Pratt's 'seeing-man.' Since Melville's time there, the Marquesas Islands had been brutally assaulted by successive epidemic outbreaks of introduced diseases: in particular, smallpox and tuberculosis. Frederick O'Brien estimated the pre-contact population of the Marquesas at approximately 160,000 people, although more recent writers such as lan Campbell have estimated a lower 1773 population of 100,000 (2011, p. 196). Whichever the preferred pre-contact figure, O'Brien's startling calculation that by 1919 only 2100 Marquesans had survived tallies with modern estimates and remains a tragic and brutal statement of loss (White Shadows, 1920, p. 129). These writers also understood that epidemics impact not only the physical body, and noted the depressing repercussions on Islander spiritual and psychological wellbeing due to drastic cultural change that was as much a potential killer as tuberculosis or smallpox. Their encounters with tropical place and Pacific persons are meeting 
eTropic 20.1 (2021) Special Issue: Pandemic, Plague, Pestilence and the Tropics

points of their rational, ordered, Western selves; and of the seeming disorder, unpredictability, and chaos around them that could so easily end in sickness and death.

\section{Tropical Mortuaries}

To understand the significance of these encounters, we need to briefly review some of the cultural history of the 'fatal impact' of Westerners on Pacific peoples. Because of the isolated nature of Pacific island geography, historic contact between Islanders and Europeans had been minimal prior to Captain Cook's three voyages and subsequent numerous landfalls throughout the Pacific, and Islanders had no immunity to many contagious diseases such as measles, smallpox, tuberculosis, syphilis, and leprosy. The key to the West's ability to dominate and conquer, then, may not have lain in who they were, but in what they brought with them: in this case, microbes. The result was that, as Patrick Brantlinger sums up so astutely, "from the time of Captain James Cook's momentous voyages between 1768 and 1779, the advent of Europeans spelled the transformation of South Pacific paradises . . . into tropical mortuaries" (2003, p. 141). Smallpox was by far the most destructive of these microbes, but venereal diseases also decimated Pacific Islanders; as syphilis spread through Pacific island populations it caused sterility and lowered birth rates, increasing depopulation already occurring due to influenza and smallpox deaths. Clearly, "few islands could have escaped lightly from the impact of foreigners in the Pacific. The population loss was severe and widespread" (Campbell, 2011, 198). Add leprosy to the fatal mix, and by the end of the nineteenth century the Pacific paradise of Melville's writings was now the disease-ravaged Pacific of the writings of Stevenson, Becke, London, and O'Brien.

What Westerners of the time evidently could not understand was that even if they believed they were racially superior and had arrived because of divine will, they were not masters of the biological changes they triggered throughout this remote Pacific world. Epidemic diseases such as smallpox, measles, and tuberculosis, which regularly swept through crowded Western nations, lay dormant within ship's officers and crews as they crossed the ocean, only to find new life and victims in the unexposed populations of the South Pacific. As their germs decimated Pacific islanders, Westerners saw a greater hand in what was to them a mysterious melting away of Indigenous populations, leaving lands seemingly open to acquisition. Perhaps, they proposed, these epidemics were divine punishment for 'native' outrages such as cannibalism and infanticide. Only Christian intervention, declared missionaries, could save these people, and conversion had to happen quickly before they all perished and their souls were lost (Brantlinger, 2003, p. 142). Ironically, in converting Pacific Islanders to Christianity, missionaries frequently committed 
eTropic 20.1 (2021) Special Issue: Pandemic, Plague, Pestilence and the Tropics

themselves to destroying the very cultures that sustained the souls they sought to save, and the customs and languages they wanted to study.

One justification for this cultural destruction was the theory that depopulation had already begun in the Pacific before Westerners arrived, caused by warfare, infanticide, and sacrificial customs (Brantlinger, 2003, 142). The missionary William Ellis, for example, supported this theory in his work Polynesian Researches [1829]. This Pacific Islander decline had been prophesied by their own priests, he maintains, and had then been hastened by the divine retribution of disease. As proof, Ellis quotes a Tahitian prophecy recorded earlier by John Davies in 1815:

The hibiscus shall grow, the coral shall spread or stretch out its branches, but man shall cease (Ellis, [1829] 1969, p. 103).

Ellis explains that the hibiscus was a rapidly spreading plant that invaded cultivated land, and that the species of branching coral could rapidly fill gaps in a lagoon that had previously allowed the passage of fish and canoes (1969, pp. 103-104). This was a warning that the traditional gods would punish the island by depriving the inhabitants of essential resources if they disobeyed the Indigenous priests. However, according to Davies and Ellis, because the old gods were not able to prevent the population from dying of disease, the Islanders had ignored this warning and accepted the Christian faith propounded by the missionaries who had enabled them to survive (1969, p. 104). Ellis uses this prophecy as an example of the triumph of Christian morals over what he took to be the immorality of animism, but, as we shall see, the collection of authors whose work we are going to explore also indulged in versions of this verse - with various intentions.

\section{Herman Melville and Typee}

Having deserted from his whaling ship in the Marquesas in 1842, the young Herman Melville remained for a short time on the largest island, Nuku Hiva, before returning to America where he wrote an account of his experience. Typee: A Peep at Polynesian Life (orig. 1846), his most popular published work during his lifetime, is a romanticised novelisation based on the castaway beachcomber experience that would become such a fashionable genre in Pacific literature (O'Brien, 2006, p. 145-6). Although Typee is set in a valley that Melville likens to "the gardens of paradise" (Rennie, 1995, p.190), he perceives a society that is already being affected by contact with European and American outsiders. "Among the islands of Polynesia," he declares, "no sooner are the images overturned, the temples demolished, and the idolaters converted into nominal Christians, than disease, vice, and premature death make their appearance" (Typee, 1982 [1846], p. 230). He accuses missionaries of being propagandists who 
eTropic 20.1 (2021) Special Issue: Pandemic, Plague, Pestilence and the Tropics

exaggerate the savagery of island conditions to further their own promotion of enlightenment. "Let the savages be civilized," he pleads, "but civilize them with benefits, and not with evils" (1982 [1846], p. 230). But it was not to be, and Typee and his later Omoo: A Narrative of Adventures in the South Seas (orig. 1847) resonate with anger and dismay at the detrimental changes occurring in the Marquesas and Society Islands that culminate in Melville's condemnation of all transformative missions, be they religious, economic, governmental, cultural, or scientific fact-gathering.

As Melville sails through a pestilent Pacific, just as Jack London likewise would during his later Pacific voyage in the Snark, he encounters Island populations and cultures already declining and dying - for which he lays the blame squarely on the intrusion of Western societies. "The enormities perpetrated in the South Seas upon some of the inoffensive islanders well-nigh pass belief," he states. "These things . . . happen at the very ends of the earth; they are done in a corner and there are none to reveal them" (1982 [1846], p. 37). Taking up the Tahitian prophecy previously recorded by Ellis, Melville rewrites the passage as:

'The coral waxes, the palm grows, and man departs,' says the Marquesan, and then he folds his hands (1982 [1846], p. 52).

Placing this prophecy in the mouth of a Marquesan Islander, instead of a Tahitian priest, alters its cultural context entirely. A prophecy of divine retribution to be enacted within a specific island environment becomes a trite justification of Islander fatalism in the face of death and depopulation. In replacing the hibiscus flower with the palm tree, Melville has inadvertently exemplified his own point that those not of the islands do not understand the culture they are destroying. In the Marquesan valley of the Taipi [Typee] people, Melville found a society still strong and vibrant, a physically perfect race who "in beauty of form surpassed anything I had ever seen," he marvels, and as far as he was concerned this remarkable, fragile beauty was directly due to the absence of interaction with Westerners (1982 [1846], p. 213-214). He was right, for only a few years later Robert Louis Stevenson would also bear witness to this same people's degradation and depopulation, their chronic illnesses and despair, and lament the destruction of the proud, strong people of Melville's novel (Stevenson, In the South Seas, 1922, p. 45-67).

\section{Robert Louis Stevenson, In the South Seas}

Both Typee and Omoo were as popular and influential outside the United States as within. Robert Louis Stevenson, for example, read them as a boy in Scotland and later claimed that they had encouraged a yearning in him to travel to the Pacific Islands (South Sea Tales, 1999, p. ix). However, by the time Stevenson eventually embarked 
eTropic 20.1 (2021) Special Issue: Pandemic, Plague, Pestilence and the Tropics

on his voyages through the Pacific, his constitution was nearly broken by a long battle with tuberculosis. Informed by his doctors that he must find a warmer climate or perish, Stevenson gained a commission to write travel articles for newspapers, and consequently he and his family made three voyages through the Pacific between 1888 and 1890, visiting most of the major island groups, including the Marquesas. Feeling that the tropical climate ameliorated his physical condition, he then settled in Samoa in 1890 for what would be the last four years of his life. His tuberculosis, and its accompanying spectre of an early death, prompted a natural empathy for the misery and disease he witnessed among Islanders, and which was expressed in his account of the voyages, In The South Seas (1922). Clearly thrilled to be following in the footsteps of his admired predecessor, he even planned his voyages to follow Melville's path through the Pacific (1922, p. 45). However, like Melville, Stevenson became disillusioned when he witnessed the reality of dispirited and diseased Islanders in contrast to the groups of ne'er-do-well whites drifting from island to island, along with profit-minded officials and missionaries bent on eradicating what they considered to be degrading and heathenish Islander customs. In their wake, many once-vibrant island societies were dying.

Although Stevenson had a reputation as a writer of romance and adventure, some of the first works of realism set in the South Seas came from his pen during these last few years of his life. Two themes would dominate these tales: the psychological devastation among Islanders caused by widespread epidemics and mortality; and the spiritual and moral blight that seemed to affect so many of the Westerners in the Pacific, corrupting their motives and actions. Stevenson dealt with these themes using different genres - addressing the Islanders in his non-fiction and travelogues, while focusing on the whites in his fiction. The Ebb-Tide, for example, is predominantly about the European experience in the Pacific. Yet as his writing progressed, his responses to those experiences evolved from boyish enthusiasm to a dying man's profound empathy with the Islanders involved in them. In the end, the islands of the South Pacific, and the plight of its Indigenous peoples, resonated with him deeply, inspiring some of his best work.

Initially, each island was for Stevenson a sensual encounter. "The first experience can never be repeated," he marvels at the beginning of In the South Seas. "The first love, the first sunrise, the first South Sea island, are memories apart, and touched a virginity of sense" (1922, p. 14-15). As his stay lengthened, he realised that although only one island could be the first, every island was an unknown world awaiting discovery: a new beginning. "Here was a fresh experience," anticipates the trader Wiltshire as he makes landfall in 'The Beach of Falesa'. "Even the tongue would be quite strange to me," he continues, "and the look of these woods and mountains, and the rare smell of them, renewed my blood" (Stevenson, 1999, p. 3). Yet, warns Stevenson in The Ebb-Tide, 
eTropic 20.1 (2021) Special Issue: Pandemic, Plague, Pestilence and the Tropics

these "undiscovered, the scarce believed-in" isles, hide the darkness of disease (1996: 75). Here, Herrick and his companions land on their dream island of white sands and green foliage only to find that smallpox has arrived ahead of them and twenty-nine of the thirty-three inhabitants have already died (1996, p. 82). Indeed, the longer Stevenson stayed and became involved in the reality of the South Seas, the more he realised that while each island might well be a new world, the entire Pacific was in fact an engrossing but complex world of economic, political, and environmental upheavals in which the impact of European colonisation often outraged him.

The Marquesas island group was both Stevenson's first destination and perhaps the most dismaying of the archipelagos he visited. Heading first for the Marquesas was understandable; after all, the island of Nuku Hiva was the setting for Melville's Typee, and so Stevenson saw it as a fitting location for his initiation into tropical life. Just like Jack London almost twenty years later, Stevenson had formed many of his fanciful ideas of the idyllic South Seas from reading Typee. He, too, borrows Melville's quotation from Ellis, but again changes wording and context. Referring to it as a "sad Tahitian proverb," and noting that reef, palm, and islander share the beach, he writes:

The coral waxes, the palm grows, but man departs (1922, p. 18).

Implying that of the three, Nature will still be there after the islanders have died out, these lines become part of Stevenson's rhapsody on the Marquesan landscape and the physical perfection of the Islanders, and he is under no illusion about the mortality of this perfection. "There is no race more viable, and yet death reaps them with both hands," he mourns (1922, p. 45). Here, where disease and depopulation have conspired to create an atmosphere of emotional surrender, Stevenson hears a young Nukuhivan woman prophesy not only the death of her infant, but the death of them all (1922, p. 44). As in so many other places in the Pacific, disease is taking a toll on the Marquesans which leaves Stevenson "staggered." Around the time Melville visited the valley of Hapaa on Nuku Hiva, he notes, the population there was estimated at around four hundred, but the combined devastation of smallpox and tuberculosis has reduced that number to only two in a span of eighteen months. Of a family of seventeen stricken by tuberculosis, only one has survived (1922, p. 46). Other factors were in play as well: here in the Marquesas, as in Hawai'i, the population was in the grip of opium addiction and there was a drop in birth rates because of the effects of venereal disease. Consequently, Stevenson estimates that within forty years the wider area population had plummeted from six thousand to less than four hundred (1922, p. 24). In the next valley, he finds only empty foundations where once there had been numerous houses. Unsurprisingly, he observes that the Islanders had become profoundly depressed, suffering what he terms "a disease . . . of the will," where they fall "easily into despondency ... a and sadness detaches him from life" (1922, p. 62). 
eTropic 20.1 (2021) Special Issue: Pandemic, Plague, Pestilence and the Tropics

So despairing and depressed had the Islanders become, he records, that rather than wait to be infected and die, they were killing themselves (1922, p. 50). There had been too much change too quickly, Stevenson concludes: "Where there have been fewest changes ... there the race survives. Where there have been most . . there it perishes" (1922, p. 63). A dying Stevenson had encountered what he perceives could be a dying Pacific.

However, as Stevenson voyages further by yacht and pen into the Pacific - beyond the Marquesas to the Paumotus, and then to the Gilbert group - In The South Seas becomes an account of "rebirth into an oceanic world capable of adaption and survival" (Edmond, 1997, 167). As he literally sails farther away from his European origins and feels more comfortable in his new environment, his writing about the Pacific also voyages farther from traditional European literary tropes and more becomes more alert to conventions of the region. Although he represents his entry into the Pacific as a meeting with death, Stevenson became so fascinated by and alert to the region's metamorphosis, and intrigued by its history and political future, that he decided to live there, writing one of the great historical texts of the Pacific, A Footnote to History: Eight Years of Trouble in Samoa (1892).

\section{Louis Becke, the Trader Author}

Like Melville and Stevenson before him, the writing of Australian Louis Becke was informed by his experiences. Living and working among Pacific islands over a period of about twelve years, he packed a lot into that time as sailor, trader, explorer, and ethnographer. Becke's prolific fiction and non-fiction ouvre of some thirty-five volumes provides a valuable insight into the Pacific of the late nineteenth century that has been largely forgotten in more recent times by critics and historians alike. While Becke's literary work about the Pacific does not reference sickness and disease as frequently as that of Stevenson, London, or O'Brien, those issues certainly did not escape his notice. In his 1897 collection of articles and stories, Wild Life in the Southern Seas, he laments the depopulating of the Ellice Islands atoll clusters of Nukulaelae and Funafuti (now part of the nation of Tuvulu), initially by Chileans kidnapping and enslaving islanders as labourers. Then, following the islands becoming a provisioning port for whaling ships, death from "unknown and terrible diseases introduced by the white men," had "ravaged not Funafuti alone, but the whole group, and where there were once thousands, only hundreds could be counted." Becke claims that by 1880 , the population of Funafuti (now the capital) had been reduced to only 170 people. So it seemed to him for a while that the Ellice (Tuvulu) Islanders might die out - although he later became more confident of their survival (1897, p. 24). 
eTropic 20.1 (2021) Special Issue: Pandemic, Plague, Pestilence and the Tropics

In the late 1880s, re-visiting the small French Polynesian atoll of Nukutavake in the Tuamotu group, Becke is shocked to the point of not being able to eat on finding that, during the years since he'd last seen them, "Death, in the hideous shape of small-pox, had been busy, taking the young and strong" (The Call of the South, 1908, p. 203). The population had been infected by the crew of a ship from Tahiti, the Islanders tell him, and in less than two months, one in three of the 310 Islanders had died. Those who had not become ill had then suffered from famine due to prolonged drought. God has deserted them, they declare, but the pragmatic Becke assures them God had nothing to do with it. Ordering supplies of food to be landed from his ship, he informs the Islanders that all the nearby islands had undergone the same periodically occurring drought, but rain was now already falling there as it would on this island within days. Which it did (1908, pp. 204-5). Becke declared more than once that Islander survival had nothing to do with the influence or activities of God or missionaries. On the contrary, when missionaries on Rakahanga and Manihiki in the Cook Islands blamed disease and depopulation on Islander women's immoral sexual behaviour with visiting whalers, Becke laid the blame squarely with missionaries whose policy of clothing Islanders in woollen Western-style garments was, he fumes, "disastrous." For centuries, these Islanders had successfully survived in their tropical environment wearing very little, and yet the Christian missionaries, "by some incomprehensible fatuity," had decided they needed to wear heavy clothes that became damp and then chilled them at night, leaving them prone to respiratory infection (1897, p. 108). Even the Islanders, he argued, asserted "that the ravages of pulmonary disease, to which they are particularly liable, first began to decimate them after they accepted Christianity" (1897, p. 109). Becke felt so strongly about these issues that he reiterated these claims about the causes of "the dreadful effects of European diseases" in a 1911 Sydney Morning Herald newspaper article, "The Dying-Out South Sea Islander." Referring to Strong's Island, now Kosrae, he described how disease had decimated the population "as it swept through them like a blast from Hell itself," reducing the population from thousands to less than 500 in only a few years (p. 7). He refutes theories that alcohol and firearms were the main causes of depopulation. Instead, he declares, it has been due to the wholesale adoption of European clothes and customs and to introduced European disease. Yet he remains adamant that, for many and complex reasons, while many will die, some will live and depopulation will not necessarily become extinction (1911, p. 7).

In one of his rare stories completely set on an island decimated by disease, 'Addie Ransom: A Memory of the Tokelaus', the Christian faith of the Nukutavau Islanders proves futile in preventing death from cholera brought there by some "infernal missionary brig" (1899, p. 116). Yet, the church bell still rings for service, "though half of the people are dead, and the other half are dying like rotten sheep," curses Wallis, one of the resident traders $(1899$, p. 115). This time, the version of Ellis' Tahitian 
eTropic 20.1 (2021) Special Issue: Pandemic, Plague, Pestilence and the Tropics

prophesy, derived from the Biblical book of Isaiah (40:7), is placed by Becke in the mouth of the island pastor:

The grass withereth, the flower fadeth, because the spirit of the Lord bloweth upon it. Surely the people is grass (1899, p. 117).

The people are dying, the pastor implies, as a result of divine will. Not so, responds Becke: death has a will of its own. The question of divine will in the face of epidemic is raised again in another Becke story, "Susani," set on the islet of Funafala, part of Funafuti atoll in what is now Tuvalu. At the time of this story, Funafala has actually been abandoned in favour of the main island because most of the people had vanished "before the breath of the white man and his civilization and 'benefits,' which to the brown people mean death" (The Tapu of Banderah, 1901, p. 271). There, the narrator meets Susani, a young one-armed girl referred to as being "in God's special keeping" (1901, p. 276) for she wanders the island alone communing with nature and no harm ever comes to her. "God hath afflicted her, but yet He doth protect her," the local church deacon tells him (1901, p. 279). While it might appear to some observers that she is mentally challenged, Becke's protagonist declares she is instead blessed of God who has given her special insight. Yet, a year later when the narrator returns, disease has stricken them all, even Susani, and they arrive just in time to witness her death and hear her last words of blessing. Even being in 'God's special keeping' has not saved her in the face of the white man's disease, but yet her death has brought Islander and European together in this unlikely place in the Pacific.

\section{Jack London's Pacific Cruise of the Snark}

Jack London's yearning for the vast, tropical, Pacific Ocean with its scattered islands was also nurtured during his childhood reading of Melville and Robert Louis Stevenson. Reading Typee, he wrote in The Cruise of the Snark, "I dreamed over its pages ... . and resolved there and then, mightily, come what would, that when I had gained strength and years, I, too, would voyage to Typee" (1911, p. 138). Like Stevenson, he embarked on a voyage that would include many of the islands that Melville and Stevenson had visited, but initially he had only a fraction of his predecessor's empathy for the Islanders' situation. Self-taught and self-assured, London revelled in the extreme supremacist implications of the philosophies of both Fredrich Nietzsche and Herbert Spencer, viewing the white race as one of übermensches triumphing over the lower races in a Darwinian struggle for mastery. However, his own eventual struggle with tropical illness would lead to a more empathetic outlook. 
eTropic 20.1 (2021) Special Issue: Pandemic, Plague, Pestilence and the Tropics

Like Stevenson, Jack London is disillusioned when he finally reaches the valley of the Typee. "The Marquesans are perishing," he laments. Here, "life faints and stumbles and gasps itself away." Even in this "truly terrestrial paradise", asthma and tuberculosis are flourishing, and "everywhere, from the few grass huts, arises the racking cough or exhausted groan of wasted lungs." In valley after valley, "the last inhabitant has passed and the fertile soil has relapsed to jungle." The once-flourishing valley of Hapaa is now an "untenanted, howling, tropical wilderness" (1911, p. 144-5). Where Melville had lived among populous Edenic gardens, London finds a jungle inhabited by only a few lepers and Islanders dying of tuberculosis. The valley of Typee is "the abode of death," he mourns, "and the dozen survivors of the tribe were gasping feebly the last painful breaths of the race" (1911, p. 148). These people once lauded for their strength and beauty, living in an environment pure from the "microbes of disease," are being destroyed by contact with outsiders who have brought those very microbes with them (1911, p. 149). London initially puts this depopulation down to Social Darwinism. The white race, although it flourished "on impurity and corruption," was enabled to survive by a herd immunity derived from that very impurity, and thus natural selection ran its inevitable course. "We who are alive are the immune, the fit - the ones best constituted to live in a world of hostile micro-organisms," London propounds (1911, p. 150).

Yet as he sailed farther across the Pacific, London's convictions about survival of the fittest were severely tested. The man who judged the deaths of tropical Islanders from introduced disease as part of nature's course now found himself ill from diseases of the tropics. In Samoa, London suffered from a worsening leg ulcer that proved unresponsive to treatment and quickly turned into a serious case of infectious yaws. By the time they were sailing through the Solomons, everyone on the ship was suffering from them. "The Snark has been a hospital for months," London writes (1911, p. 275). The more distance they sailed, the longer grew the list of tropical maladies suffered by London and others on board: ptomaine poisoning, malaria, rheumatism, and blackwater fever. Finally, the tropics literally got under London's skin. Layer after layer of skin began to peel from his hands and body until he feared he had contracted leprosy from visiting the isolation colony on the Hawaiian island of Molokai; however, he had probably developed a severe case of ultra-violet light sensitivity. Eventually, he became so ill that their voyage on the Snark had to be abandoned while he was hospitalised in Sydney for five weeks, which was then followed by five months of recovery (1911, p. 281).

This journey into his own heart of darkness caused London to re-assess his assumptions about the superiority of the white race. He was forced into an admission about the defects of his body that shattered the foundations of the philosophy by which he had lived his life; an admission that would induce a profound change. After his return to California, and for the final seven years of his life, an empathy towards illness and infection was reflected in 
eTropic 20.1 (2021) Special Issue: Pandemic, Plague, Pestilence and the Tropics

his writing. Two examples that best evidence this change are the stories 'Good-bye, Jack' and 'Koolau the Leper' from his 1912 collection The House of Pride. "The legible evidence of Western disease on blemished native bodies haunted writing about the South Pacific from the early moments of contact," argues Rob Edmond (1997, p. 194), and these two stories are haunted, as we shall see, by the visible blemish of leprosy. In 'Good-bye, Jack,' both the character Jack Kersdale, a self-made man born of missionary parents in Hawai'i, and the narrator, can be read as versions of London: the narrator as a visitor being told about Hawai'i, including information regarding a leprosy epidemic and the leper colony on the island of Molokai; and Kersdale as the mouthpiece of the white colonial elites, spouting his fearlessness of a disease that "there wasn't a chance in a million for him or any other white man to catch" (1912, p. 105). He reveals that Hawai'i now has a bacteriological test that can detect leprosy, even though a person may have no visible signs of it. Kersdale, the superior, wealthy, physically fit white superman, for whom information-gathering about leprosy is a hobby, argues in favour of legally enforced leper deportation and isolation in an adaption of London's discussion of Molokai in The Cruise of the Snark (1911, p. 81-98). He insists that living conditions at Molokai are just fine and that those forced to live there are happy; blithely adding that, "I shouldn't mind going down there myself for the rest of my days," a statement that would return to haunt him (1912, p. 105).

The two men, joining many others, go to the dock to watch the lepers being put on board the ship for Molokai, from where the "living dead" will never return. Tragedy has become a tourist attraction. Looking at the passengers, the men are reminded again of the capriciousness of a disease that has no consciousness of race or age: many of the passengers, children as well as adults, whites as well as islanders, show no outward sign of leprosy. While Kersdale is engrossed in conversation about politics - insulated and uncaring about the sorrow around him - the narrator sees among the passengers Lucy Mokunui, a famous and beautiful Hawaiian singer who has toured the United States and been associated with some of the most prominent white men in society. Yet, discovering she has the disease, this striking woman has surrendered voluntarily. The narrator is shocked at her presence: unable to even look at her, he senses in her fate the possibilities of his own. If this could happen to "the epitome of all Polynesian charms," he wonders, "what might not my lot be? - or anybody's lot?" Seeing this famous woman in this situation forces him into an awareness not only of his mortality, but that "in life, we are in the midst of death" (1912, p. 116). Then, as the ship departs, Lucy suddenly spots Jack Kersdale and, reaching out towards him, calls goodbye. Kersdale pales, and leaping into his carriage speeds to the doctor's office muttering, "I never knew" (1912, p. 123). The very virility of this white superman has exposed him to, and confronted him with, the possibility of contagion, something he has declared only happens to Islanders. Worse, Lucy has publicly 'outed' him. The implications of her sensuous farewell are unmistakable, and what may have been an open secret among that society is secret no longer: Kersdale will 
eTropic 20.1 (2021) Special Issue: Pandemic, Plague, Pestilence and the Tropics

forever be under a cloud of suspicion. In this story, London is being critical of his previous attitude. Like Kersdale, he was convinced of his invulnerability because of his belief in the power of his masculinity and white racial superiority, only to be confronted by illness during his time in the Pacific that revealed to him his mortality and vulnerability.

'Koolau the Leper' is a companion piece to 'Good-bye, Jack' in that it uses a similar situation, the exiling of leprosy sufferers on Molokai, to recast London's Darwinian social beliefs. In this case, however, the story's protagonist is an Islander. Undeceived that Molokai is really a prison, Koolau and thirty lepers resist being exiled from their home island and take shelter in a deep valley accessible only by a narrow foot trail. Unlike Lucy Mokunui, leprosy has already damaged Koolau's body and thus, visibly branded, he cannot escape detection. For a while, he and his fellow rebels make this valley their home: planting food crops, building terraces, and constructing shelters. Armed police eventually arrive to remove them but are compelled to retreat when Koolau's group open fire. Despite being shelled by artillery, the rebels hold out for another two days but eventually all surrender, except Koolau. Avoiding capture, he disappears into the mountains where he dies two years later: in his own time, with dignity and strength, still clutching his rifle. He dies still his own free person. Disease is the pivotal point of this story: Koolau would not be this person or be in this situation if not for leprosy. Here, London steps into the mind of the sufferer, rather than watching the story unfold as a 'seeing-man,' and thus Koolau has a depth not possessed by the white supremacist Kersdale, who because of his colour and race has been in denial that he might contract the disease. London grasps the social and economic divisions inherent in this epidemic; the Indigenous islanders have lost their land and livelihood and, cut off from economic access, are exposed to a disease allegedly imported by the various immigrant labourers brought in to replace them. Because of their disfigurement, they are regarded as outcasts on their own island, deemed by society to have been rejected even by God, "for upon them had been placed the mark of the beast" (1912, p. 49). Their humanity reduced in the eyes of others, they have become like animals living in caves, "creatures who had once been men and women. But they were men and women no longer. They were monsters ... who had the seeming of creatures who had been wracked in hell" (1912, p. 50). This is the writing of a Jack London who had been in his own hell, a man who truly knew not only what disease was, but what it felt like to experience and suffer with it. No longer superman, no longer the 'seeing-man,' London here reveals in this elegy the fallible man who had come to an uneasy peace with disease and death.

\section{The White Shadows of Frederick O'Brien.}

The later experience of writer Fredrick O'Brien in the Marquesas has much in common with Stevenson, Becke, and London. In fact, O'Brien knew the Londons and became a close friend of Charmian London after Jack's death in 1916. Like Becke, O'Brien turned 
eTropic 20.1 (2021) Special Issue: Pandemic, Plague, Pestilence and the Tropics

to writing books later in life, having travelled widely as a young man and then become a journalist. In 1913, he embarked on an extended journey through the South Pacific, visiting a number of islands and living in the Marquesas for a year. Despite its serious overtones and critique of the drastic and tragic impact of Western society on the South Pacific region, O'Brien's account of his sojourn in the Marquesas, White Shadows in the South Seas (1919), had an enormous impact on an American reading public seeking escape after the horrors of war, "setting in motion a wave of interest in South Pacificthemed material that would last a decade" (Geiger, 2007, p. 75). Its success was confirmed in 1928 when the title was used for MGM's first movie with sound, directed by W. S. 'Woody' van Dyke - although the plot was developed from a story in O'Brien's later Atolls of the Sun.

O'Brien became part of a post-World War I American literary movement towards a new idealised mythic frontier expressed in such novels of the period as Edison Marshall's The Strength of the Pines (1921) and Zane Grey's The Man of the Forest (1920). Like the work of O'Brien and London, Grey's later Tales of Tahitian Waters (1931) and his posthumous The Reef Girl (1977) would explore the familiar frontier trope by shifting it even further west into the Pacific. O'Brien seized upon his new-found popularity and quickly followed up White Shadows with two prequels, Mystic Isles of the South Seas (1921), and Atolls of the Sun (1922). All three books essentially narrate a single journey from San Francisco to Tahiti and on to the Tuamoto Archipelago and the Marquesas. A haunted "narrative of release mixed with memory and loss," White Shadows in the South Seas presents a paradise scarred by the tragic aftermath of 'fatal impact'. Critical and pessimistic, it does not overly romanticise this new frontier; rather, his narrative "questions the moral sanctity of frontier mentality by associating colonialism with genocide" (Geiger, 2007, p. 84). In this work, O'Brien challenges established clichés of the Pacific experience and his darker tone in many respects returns to that of Melville's critical comments about colonial impact. O'Brien's white shadows are the shadows of death, the shadows of the populations that have vanished due to contact with whiteness. In his Marquesas islands, the darkness of death remains a constant presence lurking among abundant tropical life and lushness.

Like Stevenson, London, and Becke, with whom he was familiar, O'Brien had pored over the pages of Melville as a boy and become enthralled by the dream of travelling to islands "isolated from the world for aeons" where remained "a living fragment of the childhood of our Caucasian race" (White Shadows, 1919, p.11, 21). Although his origin theories about Polynesian populations now read as outdated, O'Brien was sincerely saddened that, having finally encountered "the peoples of the great world," that 'living fragment' could now be dying as a result, and so his self-declared mission became to see Pacific Island people before they might disappear forever (1919, p. 12). This theme of impending extinction of Pacific Islanders in the wake of contact with Western society is one to which 
eTropic 20.1 (2021) Special Issue: Pandemic, Plague, Pestilence and the Tropics

O'Brien often returns, because this is all he can see will be the result of the devastation of these populations. "Their people perish," he writes, as he hikes into empty valleys "which each held a thousand or several thousand when the blight of the white man came" (1919, p. 21,102). Visiting Melville's valley of the Typee, O'Brien too finds it overgrown and fallen into ruin. In a valley nine miles long, once the home of "thousands of men and women whose bodies were as beautiful as the models for the statues the Greeks made, whose hearts were generous, and whose minds were eager to learn all good things," only a dozen sick people remain, surrounded by jungle and the empty stone foundation platforms for houses [paepaes] (1919, p. 223). Soon, he imagines, only ghosts will inhabit this place, for the Marquesan culture is disappearing along with the people. Houses built of traditional materials are being replaced by homes clad in timber planks with iron roofs; traditional axes are being replaced by guns, and ancestral songs and histories are being forgotten. O'Brien establishes a literary connection with those who have gone here before him by also indulging in ethno-ventriloquism in having an Islander speak those familiar lines introduced by Ellis:

The hibiscus shall grow, the coral shall spread, and man shall cease.

It will not be long, the Islander intones, until "We vanish like the small fish before the hunger of the mako [shark]" (1919, p. 107). For O'Brien, like some earlier writers, the Islanders have accepted their inevitable extinction. This is, of course, a perception of an outsider of this period, which is not to lessen an emotional and psychological reality. Seeing your family and relatives dying around you without any chance of aid must have engendered a demoralisation, despair, and hopelessness among Islanders that could be understood by empathetic witnesses.

Death surrounds O'Brien here amid paradise. The next ship to arrive brings with it influenza and tuberculosis, and soon those around him are coughing and dying. His neighbour coughs, then "her neighbor took it up, and then, like laughter in a school, it became impossible to resist, and down in the beach and up to the heights of the valley echoed with the distressing sounds" (1919, p. 125). Their deaths are a mutually, calmly, and fearlessly accepted inevitability, maintains O'Brien, for "this remnant of a race, overwhelmed by tragedy, can look on death only as a relief from the oppression of alien and unsympathetic white men" (1919, p. 127). Even the local Catholic priest holds the view that this island is just one example of a Polynesia that is dying. One hundred years previously there may have been 160,000 Marquesans, with 19,000 fighting men on the island of Nuka Hiva alone, estimates O'Brien, but now only 2100 Marquesans might remain alive (1919, p. 129). In their misery, the Islanders rage against the missionaries whose God seems to be punishing them and became renowned for their reluctance to convert. However, O'Brien suggests, there was another reason for Marquesan depopulation, and that was the shadow that had fallen over their cultural pursuits such as 
eTropic 20.1 (2021) Special Issue: Pandemic, Plague, Pestilence and the Tropics

dance, song, religious ceremony, and even ritual tattooing. This happy, emotional, humorous people were being denied their very heritage, and thus their mental as well as their physical well-being, under the rule of the white missionary and trader "who came here only to gratify his cupidity" (1919, p. 131). With their cultural activities, which marked the passing of the yearly round, taken away from them, Marquesans were losing their will to live a life that now seemed pointless. Even their names, which were related to their culture as each name referred to an experience or name of their ancestors and thus formed a link to their heritage, was being lost with the bestowing of English names (1919, p. 167). What would Christ think, he laments, "of the havoc wrought by men calling themselves Christians." Westerners have contributed nothing positive to these people, he concludes; they have only taken from them (1919, p. 223).

\section{Conclusion, Pacific Revival}

For Melville, Stevenson, Becke, London, and O'Brien, the Marquesas Islands were a microcosm of what was happening to the Pacific region at that time. These writers formed a unique group because of their personal relationship to a particular Pacific place, and their work reveals the dire consequences over time of colonial contact with Pacific peoples, culminating in O'Brien's conviction that their eventual extinction was inevitable. Although some of these writers did see Islanders through that prism of Social Darwinism and extinction discourse to some degree, each writer was nevertheless appalled in their own way at the catastrophic effects of depopulation due to epidemics on Pacific islands, and their writing is witness to their anguish. Instead of distancing themselves by objective language as passive 'seeing-men,' they perceived the environment and peoples of the Pacific through the medium of literary language, enabling them to interact with the authority and authenticity of first-person felt experience. In the case of Jack London, this interaction was so profound that it changed his view of the region to one more tolerant and inclusive. Louis Becke, who lived among Islanders, spoke their languages, understood their customs, and listened to their stories, became an early spokesperson about Island issues. He believed that Pacific islanders should have been allowed to retain their own culture; as far as he was concerned, the impact of missionaries and their alteration of Islander life and culture was an epidemic in itself. By the time Frederick O'Brien arrived in the Marquesas in 1913, sickness and death due to disease introduced by Westerners had devastated the population and the culture of this archipelago to such an extent that O'Brien was convinced that the extinction of the Indigenous population was imminent.

These opinions of Melville, Stevenson, Becke, London, and O'Brien about the impact of disease and epidemics on Pacific Island populations and culture were influenced by their personal experience, as well as by the cultural philosophy of the time. Rather than writing as merely Pratt's 'seeing-man,' they connected experience to person and wrote as 
eTropic 20.1 (2021) Special Issue: Pandemic, Plague, Pestilence and the Tropics

explorers, cultural historians, and inhabitants of the South Pacific region. As such, these Anglo-American voices continue to be some of the clearest and most powerful witnesses to the ravages of Western society in the Pacific Islands during the colonial period. They were not only influenced by their encounters with Pacific Islands and the impact of Western diseases, but they were profoundly influenced by their contact (in some cases, prolonged contact) with the peoples and cultures of the islands. However, not only did Westerners have an impact on the Pacific Islands, but, such as in the case of this group of colonial writers for example, the Islands had an impact on them. Literary voices such as these are significant and worth re-examining because they mark a shift in Western literary and philosophical attitude about Pacific culture, and a willingness of the writer to reposition themselves contrary to common mores in regard to that culture.

Yet, as empathetic as they may be, these are Anglo-American colonial voices speaking of a diseased environment of epidemic issues in the South Pacific region during a specific period of time. Postcolonial Pacific Island peoples now speak out with their own strong voices about issues that impinge upon the islands, that relate to the past but are also part of the present. In his magnificent elegy for the Pacific Ocean, "Praise Song for Oceania," for example, Guam poet Craig Santos Perez praises the Pacific Ocean for, among many things, "your capacity for renewal", and for "your capacity/ to endure the violation/ of those who ... pillage." Ultimately, he praises the Pacific for "our trans-oceanic/ past present and future/ flowing through/ our blood" (Perez, 2020, pp. 51-55). The Pacific environment, he suggests, lives on as the environment of us all and so deserves the care and praise of us all. In Witi Ihimaera's play, Woman Far Walking (2000), 160 years of colonial history is embodied in the figure of Te Tiuiti o Waitangi Mahana, enabling the play to explore key phases of Maori survival and struggle since colonisation, including surviving the 1918 Spanish influenza epidemic. Albert Wendt's novel The Mango's Kiss (2003) also explores the ramifications of the 1918 epidemic in the subsequent emergence of the Samoan independence organisation 'O le Mau,' providing insight not only into living through the epidemic but into both sides of the ensuing political struggle that eventually formed the present Samoa. Issues of the past are integral to the present, these writers tell us. Relationships between the West and the Pacific continue to include detrimental elements, such as nuclear contamination, the effects of Western diet, consumerism, global warming, and rising sea levels. Unfortunately, ongoing outbreaks of introduced diseases remain part of the present environment and Pacific discourses. These issues still require writers of today to bear witness.

In contemporary Islander literary discourse, that engagement with the relationship between local and global is ongoing, but now in its own voice: a new voice. As boundaries between local and global blur in the face of Islander diasporas, globalised cultures, and social media, the shared regional identity implied by Epili Hau'ofa's 
eTropic 20.1 (2021) Special Issue: Pandemic, Plague, Pestilence and the Tropics

invitation to perceive the Pacific holistically as a "sea of islands" becomes a means by which the region can survive both materially, and ideologically (1994, pp. 152-3). The continuance of Pacific literary consciousness testifies to the survival of the region as more than a romantic concept, a hope or a dream, or a 'dying pillow' that Europeans must soften, but as a manifold, diverse, cultural place. To rephrase the quotation by Diderot that prefaced this paper: Weep not, peoples of the Pacific, for the coming of the man of the past, but praise in your new voice a sea of islands that flows in your blood. 
eTropic 20.1 (2021) Special Issue: Pandemic, Plague, Pestilence and the Tropics

\section{References}

Becke, L. (1899). Addie Ransom: A Memory of the Tokelaus. In Ridan the Devil and Other Stories (pp. 115-124). T Fisher Unwin.

Becke, L. (1897). Green Dots of the Empire: The Ellis Group. In Wild Life in the Southern Seas (pp. 14 - 28). T Fisher Unwin https://doi.org/10.5962/bhl.title.146500

Becke, L. (1896, 3 September). Missionaries in the South Seas. The Age (Melbourne), 3

Becke, L. (1911, 26 August). The Dying Out South Sea Islander. The Sydney Morning Herald, 7.

Becke, L. (1908). The Dandiest Boy That Ever Stood Up in a Boat (pp. 203-210). In The Call of the South. T Fisher Unwin.

Becke, L., \& Jeffery, W. (1901). Susani. In The Tapu of Banderah (pp. 270-294). C. Arthur Pearson Ltd.

Brantlinger, P. (2003). Dark Vanishings: Discourse on the Extinction of Primitive Races 1800-1930. Cornell University Press.

Campbell, I.C. (2011). Worlds Apart: A History of the Pacific Islands (2nd Ed.). Canterbury University Press.

Edmond, R. (1997). Representing the South Pacific: Colonial Discourse from Cook to Gaugin. Cambridge University Press. https://doi.org/10.1017/CBO9780511581854

Ellis, W. (1969). Polynesian Researches: Polynesia. Charles E Tuttle \& Co. (Original work published 1829).

Geiger, J. (2007). Facing the Pacific: Polynesia and the Pacific Imagination. University of Hawai'i Press. https://doi.org/10.1515/9780824862459

Geiger, J. (2003). White Shadows in the South Seas and Cultural Ambivalence. Cinema Journal. 41 (3), 98-121. https://doi.org/10.1353/cj.2002.0008

Gravelle, K. (2012). Fiji's Heritage: A History of Fiji. Tiara Enterprises.

Hau'ofa, E. (1993, Spring). Our Sea of Islands. The Contemporary Pacific. 6 (1), 148-161. Ihimaera, W. (2000). Woman Far Walking. Huia Publishers.

Jolly, R. (1999). Introduction. In Robert Louis Stevenson, South Sea Tales (pp. ix-xxxiii). Oxford University Press.

Judd, C. S. Jr. (1977, Winter). Depopulation in Polynesia. Bulletin of the History of Medicine. $51(4), 585-593$.

London, J. (1914). Koolau The Leper. In The House of Pride (pp. 47-91). Grosset \& Dunlap. London, J. (1911). Good-bye, Jack. In The House of Pride (pp. 95-123). Grosset \& Dunlap. London, J. (1911). The Cruise of the Snark. M. A. Donohue and Co.

Melville, H. (1982). Typee: A Peep at Polynesian Life; Omoo: A Narrative of Adventures in the South Seas; Mardi and a Voyage Thither. The Library of America/Viking Press. (Typee originally published 1846 . Omoo originally published 1847. Mardi originally published 1849).

Moorehead, A. (1966). The Fatal Impact: An Account of the Invasion of the South Pacific. Hamish Hamilton.

O'Brien, F. (1922). Atolls of the South Seas. Hodder and Stoughton.

O'Brien, F. (1921). Mystic Isles of the South Seas. Hodder and Stoughton.

O'Brien, F. (1920). White Shadows in the South Seas. Hodder and Stoughton.

O'Brien, P. (2006). The Pacific Muse: Exotic Femininity and the Colonial Pacific. University of Washington Press.

Perez, C. S. (2020). Poems ("Praise Song for Oceania"). eTropic: electronic journal of studies in the tropics, 19 (1), 51-55. https://doi.org/10.25120/etropic.19.1.2020.3676

Pratt, M. L. (1992). Imperial Eyes: Travel Writing and Transculturation. Routledge. https://doi.org/10.4324/9780203163672 
eTropic 20.1 (2021) Special Issue: Pandemic, Plague, Pestilence and the Tropics

Rennie, N. (1995). Far-Fetched Facts: The Literature of Travel and the Idea of the South Seas. Clarendon Press.

Stevenson, R. L. (1999). The Beach of Falesá. In South Sea Tales (pp. 3-72). Oxford University Press. (Originally published in book form 1894).

Stevenson, R. L. (1996). The Ebb-Tide. J M Dent/Everyman. (Originally published in book form 1894).

Stevenson, R. L. (1922). In the South Seas. In The Works of Robert Louis Stevenson (Vailima Edition, Vol. 16, pp.1-443). William Heinemann.

Thompson, C. (2019). Sea People: The Puzzle of Polynesia. William Collins.

Wendt, A. (2003). The Mango's Kiss. Random House New Zealand.

Dr Chrystopher J. Spicer has written extensively on Australian and American literary and cultural studies in a number of books and papers. His latest book is Cyclone Country: The Language of Place and Disaster in Australian Literature (McFarland, 2020). He is currently a cultural historian and a Senior Research Fellow (Adj) at James Cook University, Cairns, Queensland. 